\title{
PENERAPAN TEKNOLOGI PENGOLAHAN DODOL SIRSAK PADA KELOMPOK PROGRAM KELUARGA HARAPAN (PKH) KELURAHAN PAYOBASUNG, KECAMATAN PAYAKUMBUH TIMUR, KOTA PAYAKUMBUH
}

\section{THE IMPLEMENTATION OF SOURSOP DODOL PROCESSING TECHNOLOGY IN PROGRAM KELUARGA HARAPAN (PKH) GROUP OF PAYOBASUNG VILLAGE, PAYAKUMBUH TIMUR SUB-DISTRICT, PAYAKUMBUH CITY}

\author{
Ermiati $^{1{ }^{*}}$, Elva Amurita Zebua ${ }^{2)}$, Agustina $^{3)}$, Syuryani Syahrul ${ }^{4)}$, Evawati ${ }^{5)}$ \\ ${ }^{1)}$ Program Studi Teknologi Pangan, Politeknik Pertanian Negeri Payakumbuh \\ email: munirermiati@gmail.com \\ ${ }^{2)}$ Program Studi Teknologi Pangan, Politeknik Pertanian Negeri Payakumbuh \\ email: amuritazebua@gmail.com \\ ${ }^{3)}$ Program Studi Teknologi Pangan, Politeknik Pertanian Negeri Payakumbuh \\ email: agustina.atina@gmail.com \\ ${ }^{4)}$ Program Studi Teknologi Pangan, Politeknik Pertanian Negeri Payakumbuh \\ email: syuryani.syahrul@ politanipyk.ac.id \\ ${ }^{5)}$ Program Studi Teknologi Pangan, Politeknik Pertanian Negeri Payakumbuh \\ email: evawati.politani@gmail.com
}

\begin{abstract}
ABSTRAK
Sirsak merupakan salah satu komoditi yang banyak dijumpai di pekarangan masyarakat di Kelurahan Payobasung Kecamatan Payakumbuh Timur, Kota Payakumbuh. Pengolahan dan pemanfaatan sirsak oleh masyarakat di Kelurahan Payobasung ini masih sangat minim dan terbatas. Sirsak dapat diolah menjadi aneka makanan, salah satunya adalah dodol. Pengolahan dodol sirsak dapat dilakukan dengan cara pemasakan yang sederhana dan menggunakan peralatan yang sederhana, sehingga dapat diaplikasikan pada industri skala rumah tangga. Berdasarkan hal tersebut, maka dilakukan kegiatan pengabdian dan pendampingan terhadap kelompok PKH Kelurahan Payobasung. Kegiatan ini bertujuan untuk meningkatkan wawasan dan keterampilan peserta dalam mengolah sirsak menjadi dodol sirsak, dan mengarahkan keterampilan tersebut untuk menghasilkan pendapatan dan meningkatkan perekonomian keluarga. Pendampingan dilakukan dengan memberikan sosialisasi, pelatihan dan demo mengenai teknologi pengolahan dodol sirsak mulai dari persiapan bahan baku hingga proses pengemasan, serta usaha-usaha pemasaran kepada para peserta pelatihan. Hasil kegiatan ini adalah adanya peningkatan wawasan, keterampilan peserta mengenai pembuatan dodol sirsak, dan diharapkan ada peningkatan pendapatan bagi keluarga penerima PKH di Kelurahan Payobasung.
\end{abstract}

Kata kunci: Dodol, Sirsak, Komoditi Pekarangan

\section{ABSTRACT}

Soursop is a garden commodity that is often found in community's yard and garden of Payobasung Village, Payakumbuh Timur Sub-District, Payakumbuh City. The processing and utilization of soursop by Payobasung Village community was minimal and limited. Soursop can be processed into various foods, including dodol. The processing of soursop dodol can be done by simple cooking and use simple equipment, so can be applied on a household scale industry. Based on this background, community service and assistance activities were carried out for PKH groups of Payobasung Village. The aims of this activity were to increase the perception and skills of participants in processing soursop into soursop dodol, and directing their skills to generate income and improve the family economy. The assistance activity was done by providing socialization, training and demonstration about the technology of soursop dodol, starting from the preparation of raw materials to the packaging process, as well as marketing efforts to the training participants. The results of this activity indicated an increase in participants' perception and skills regarding making soursop dodol, and it is hoped that 
there will be an increase in income for PKH recipient families in Payobasung Village.

Keywords: Dodol, Soursop, Garden Comodity

\section{PENDAHULUAN}

Program Keluarga Harapan (PKH) merupakan salah satu program pemerintah yang memberi bantuan sosial bersyarat kepada keluarga miskin yang ditetapkan sebagai keluarga penerima manfaat $\mathrm{PKH}$ dengan tujuan untuk menurunkan jumlah penduduk miskin di Indonesia. Kelompok penerima $\mathrm{PKH}$ diarahkan menjadi pusat keunggulan penanggulangan kemiskinan yang disinergikan dengan berbagai program perlindungan dan pemberdayaan sosial nasional dengan memanfaatkan pelayanan sosial dasar kesehatan, pendidikan, pangan dan gizi [1].

Pada tahun 2019, jumlah penerima manfaat Program Keluarga Harapan (PKH) di Kota Payakumbuh adalah 3.713 keluarga yang tersebar di berbagai kecamatan yang ada di kota Payakumbuh termasuk kecamatan Payakumbuh Timur. Terdapat sembilan kelurahan di Kecamatan Payakumbuh Timur yang mendapat program PKH salah satunya kelurahan Payobasung. Jumlah penerima PKH di kelurahan Payobasung adalah 56 keluarga. Para penerima PKH umumnya merupakan ibu rumah tangga yang tidak mempunyai penghasilan tetap [2].

Program Studi Teknologi Pangan Politeknik Pertanian Negeri Payakumbuh bekerja sama dengan Dinas Sosial Kota Payakumbuh mengadakan kegiatan pemberdayaan masyarakat berupa pelatihan pengolahan pangan bagi penerima $\mathrm{PKH}$ di
Kelurahan Payobasung, Kecamatan Payakumbuh Timur. Pelatihan pengolahan pangan merupakan salah satu bentuk pelayanan dosen di Program Studi Teknologi Pangan, Politani Payakumbuh sebagai wujud nyata pengabdian kepada masyarakat. Tujuan PKH untuk merubah taraf hidup keluarga penerima manfaat PKH menjadi mandiri, berdaya saing dan sejahtera dapat dicapai dengan mengadakan pelatihan pengolahan pangan memanfaatkan pangan lokal dan tanaman pekarangan.

Salah satu tanaman pekarangan yang dapat diolah menjadi pangan bernilai ekonomi tinggi adalah sirsak. Sirsak merupakan tanaman pekarangan yang menghasilkan buah dan mampu tumbuh dan beradaptasi dengan baik di tanah kering ${ }^{[3]}$. Buah sirsak (Annona muricata) memiliki tekstur yang lunak dan kandungan gula yang tinggi sehingga banyak diolah menjadi dodol $[4,5]$.

Dodol adalah salah satu makanan ringan tradisional Indonesia dengan bahan baku utama tepung beras ketan dan buah-buahan. Dodol memiliki jenis yang beragam tergantung cara pembuatan dan campuran bahan tambahannya. Dodol yang diolah secara tradisional memiliki umur simpan dua minggu hingga satu bulan sehingga sangat potensial untuk dikomersialkan [5,6].

Tujuan kegiatan pengabdian kepada masyarakat ini adalah untuk meningkatkan wawasan dan keterampilan peserta dalam 
mengolah sirsak menjadi dodol sirsak, dan mengarahkan keterampilan tersebut untuk menghasilkan pendapatan dan meningkatkan perekonomian keluarga penerima $\mathrm{PKH}$ sehingga dapat mandiri dan sejahtera.

\section{METODE PELAKSANAAN KEGIATAN}

Tahap awal kegiatan pengabdian kepada masyarakat ini adalah penyusunan perencanaan pelaksanaan pelatihan yang bekerja sama dengan Dinas Sosial Kota Payakumbuh. Kegiatan ini meliputi penentuan jadwal dan lokasi pelatihan, agenda kegiatan pelatihan, pendataan peserta pelatihan, dan penyusunan materi pelatihan.

Informasi mengenai permasalahan yang dialami oleh mitra pengabdian dilakukan melalui diskusi bersama tim pendamping PKH dari Dinas Sosial Kota Payakumbuh. Selanjutnya tim menganalisis permasalahan dan menawarkan solusi melalui program pelatihan penerapan teknologi pengolahan pangan dengan memanfaatkan tanaman pekarangan yang banyak dijumpai di pekarangan masyarakat Kelurahan Payobasung, Kecamatan Payakumbuh Timur serta pemaparan materi seputar kewirausahaan yang dapat dijalankan dengan penerapan teknologi tersebut.

Tahap kedua kegiatan pengabdian kepada masyarakat ini adalah kegiatan pelatihan pengolahan dodol sirsak kepada peserta pelatihan. Pada kegiatan ini dilakuakan sosialisasi atau pemaparan materi tentang potensi pengolahan sirsak menjadi dodol sirsak. Selanjutnya dilakukan demo atau praktik pembuatan dodol sirsak, mulai dari pengenalan bahan baku, pemasakan hingga pengemasan.

Tahapan ketiga kegiatan ini berupa diskusi dengan para peserta mengenai prospek pengembangan usaha dodol sirsak dan langkah penyelesaian jika ditemui kendala dalam pengembangan usaha tersebut. Tim menawarkan solusi untuk memberi pendampingan kepada para peserta pelatihan dimana tim bersedia memberi saran dan solusi atas kendala yang ditemui peserta

\section{HASIL DAN PEMBAHASAN}

Kegiatan pengabdian telah dilaksanakan sesuai dengan jadwal yang telah disusun. Kegiatan pelatihan dibuka langsung oleh Camat Payakumbuh Timur didampingi oleh Lurah Payobasung bersama dengan tim pengabdian masyarakat Politani Payakumbuh dan tim pendamping PKH dari Dinas Sosial Kota Payakumbuh. Jumlah peserta pada kegiatan ini adalah 19 orang yang mewakili 19 keluarga penerima bantuan PKH. Pembatasan peserta dilakukan untuk mematuhi protokol kesehatan di masa pandemi Covid-19.

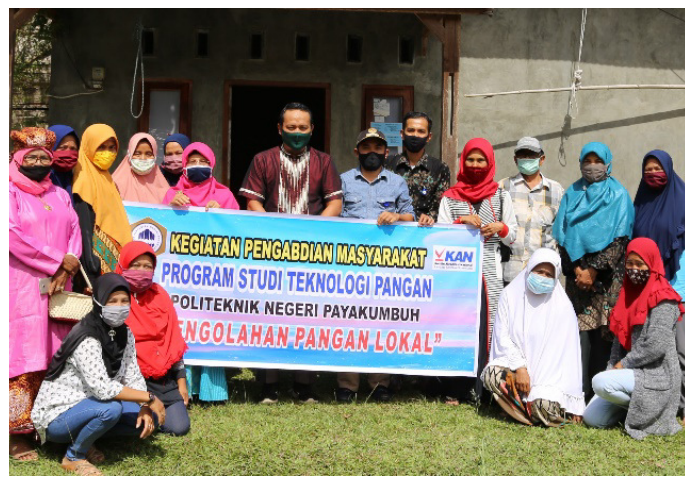

Gambar 1. Foto bersama dengan Camat Payakumbuh Timur, Lurah Payobasung, tim pendamping PKH Dinas Sosial Kota Payakumbuh, peserta pelatihan dan tim pengabdian. 
Pelaksanaan kegiatan ini dilakukan dengan menjelaskan tentang kegiatan yang akan dilakukan. Selanjutnya dilaksanakan penyampaian/ pemaparan materi mengenai sirsak dan manfaatnya bagi kesehatan, pasca panen sirsak dan umur simpannya, serta beberapa olahan pangan berbahan baku sirsak, salah satunya dodol. Tim juga memberi pejelasan mengenai keunggulan produk dodol, dimana dodol merupakan salah satu olahan pangan lokal Indonesia. Tim menyampaikan tentang teknologi yang diterapkan dalam pembuatan dodol sirsak, titik kritis pembuatan dodol dan umur simpannya.

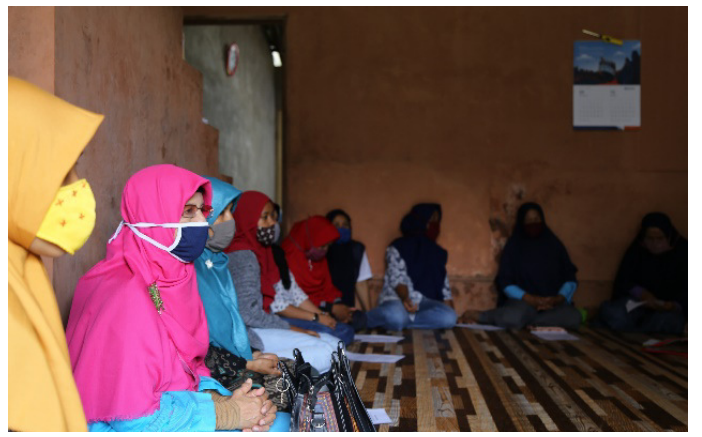

Gambar 2. Pemaparan materi tentang sirsak dan dodol sirsak

Demo pengolahan/ pembuatan dodol sirsak dilakukan setelah pemaparan materi selesai. Peserta berpartisipasi aktif dalam demo karena tim melibatkan peserta dalam proses pengolahan. Tujuan pelibatan peserta dalam demo pengolahan dodol sirsak adalah supaya peserta dapat langsung menyaksikan dan ikut mengolah dodol sirsak. Pemahaman akan proses pengolahan akan lebih mendalam jika ikut terlibat dalam proses produksi.

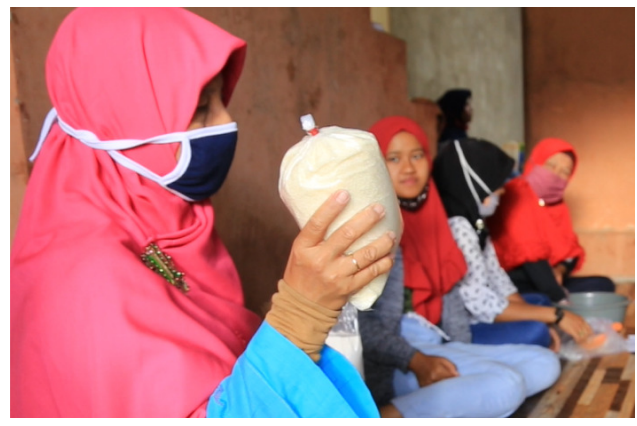

Gambar 3. Penjelasan tentang bahan baku pembuatan dodol sirsak

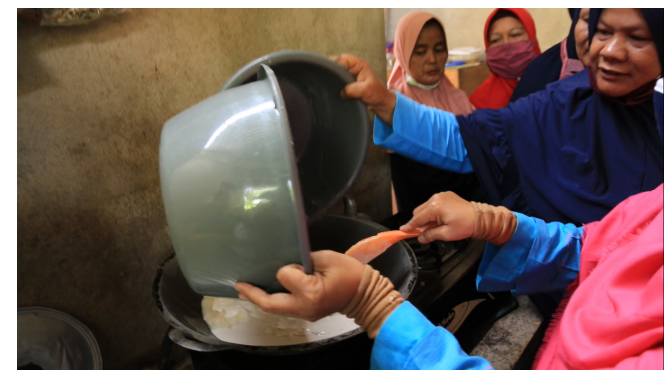

Gambar 4. Proses pengolahan dodol sirsak

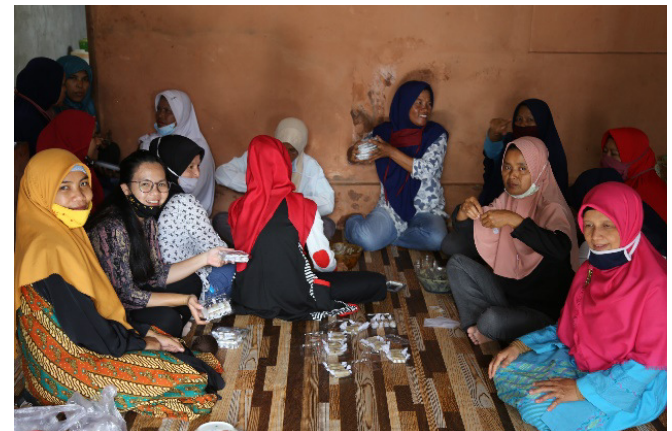

Gambar 5. Proses pengemasan dodol sirsak

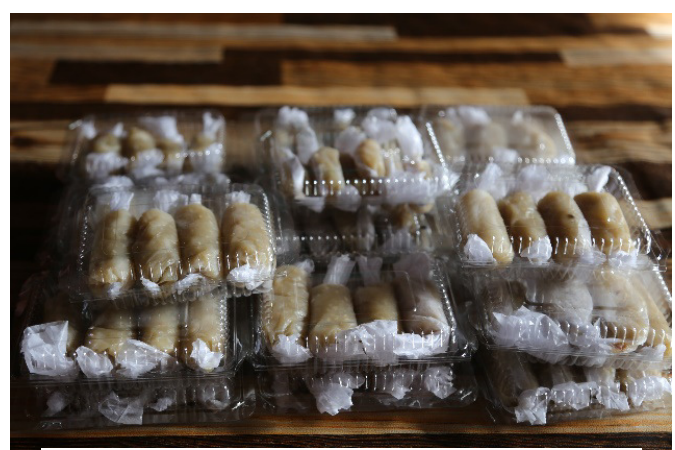

Gambar 6. Dodol sirsak yang dikemas

Setelah demo pembuatan dodol selesai, tim pengabdian dan peserta melaksanakan diskusi mengenai prospek usaha atau peluang bisnis dodol sirsak. Diskusi tersebut membahas tentang peluang bisnis dodol sirsak yang dapat dijalankan dengan modal yang cukup kecil dan dapat dijadikan sebagai 
bisnis dari rumah. Peluang bisnis dan Payobasung yang berdampak pada wirausaha dodol sirsak menjadi materi yang sangat menarik bagi peserta, terlihat dari antusiasme peserta yang sangat tinggi dalam diskusi.

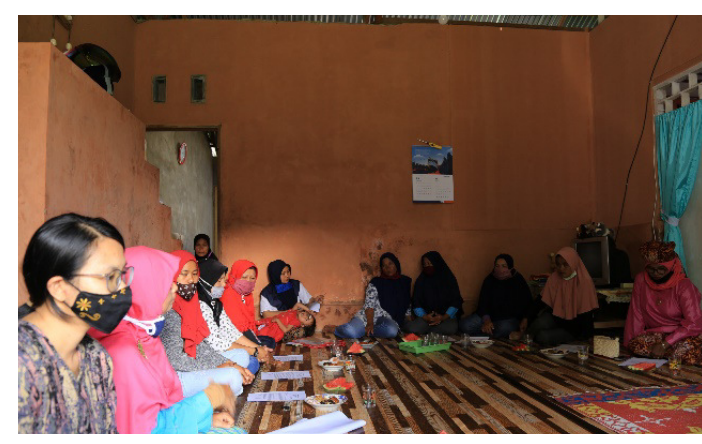

Gambar 7. Diskusi mengenai peluang bisnis dodol sirsak

Antusiasme yang tinggi dari peserta menjadi indikasi keberhasilan kegiatan pengabdian ini, karena melalui kegiatan pengabdian ini, tim dapat mengaplikasikan teknologi pengolahan dodol sirsak dengan metode yang sederhana kepada masyarakat. Tim juga berhasil memunculkan jiwa entrepreneurship para peserta pelatihan untuk melihat peluang bisnis dodol sirsak dengan memanfaatkan pangan lokal yang tumbuh dipekarangan yaitu sirsak.

Kendala yang dihadapi dalam pelaksanaan kegiatan pelatihan ini adalah pandemi Covid-19 yang masih berlangsung sehingga peserta kegiatan dibatasi hanya 19 orang. Kegiatan pelatihan dilaksanakan dengan tetap memperhatikan protokol kesehatan.

Sebagai luaran dari kegiatan pelatihan ini, tim mengharapkan peserta dapat mulai merancang dan melaksanakan pengembangkan usaha dodol sirsak sehingga dapat terbentuk kelompok usaha PKH peningkatan pendapatan keluarga. Hal ini sesuai dengan harapan Camat Payakumbuh Timur yang menginginkan agar ibu-ibu peserta pelatihan sekaligus penerima $\mathrm{PKH}$ sudah dapat mandiri dan sejahtera dan dapat keluar dari program PKH dua tahun setelah pelatihan ini berakhir [7].

Tim pengabdian bersedia memberi pendampingan terhadap peserta yang ingin mengembangkan usaha pembuatan dodol sirsak. Tim menyambut baik dan membuka ruang diskusi bagi peserta pelatihan yang ingin berdiskusi mengenai pengolahan dodol sirsak dan kendala-kendala yang dihadapi selama mengembangkan usaha tersebut.

Pada akhir kegiatan pelatihan, tim pengabdian memberikan apresiasi kepada peserta pelatihan berupa pemberian modal usaha awal yang diserahkan oleh ketua tim pengabdian.

\section{KESIMPULAN}

Teknologi pengolahan dodol sirsak berhasil direapkan kepada kelompok PHK Kelurahan Payobasung, Payakumbuh Timur. Hasil pelaksanaan kegiatan menunjukkan bahwa peserta telah memiliki pengetahuan dan skill dalam mengolah sirsak menjadi dodol sirsak. Peserta juga sangat antusias terhadap pengembangan usaha dodol sirsak.

\section{SARAN}

Diharapkan adanya tindak lanjut pendampingan pengembangan usaha dodol sirsak Kelompok PKH Payobasung. 


\section{UCAPAN TERIMAKASIH}

Penulis mengucapkan terimakasih kepada Politeknik Pertanian Negeri Payakumbuh dimana kegiatan Pengabdian Kepada Masyarakat ini terselenggara atas pendanaan dari Dana Isian Penggunaan Anggaran (DIPA) Politeknik Pertanian Negeri Payakumbuh 2020. Ucapan terimakasih juga penulis sampaikan kepada Camat Payakumbuh Timur, Lurah Payobasung, tim pendamping PKH Dinas Sosial Kota Payakumbuh dan kelompok PKH Kelurahan Payobasung, Kecamatan

Payakumbuh Timur.

\section{REFERENSI}

[1] Kemsos. 2018. Program Keluarga Harapan. https://pkh.kemsos.go.id/. Diakses tanggal 20 November 2020.

[2] Dinsos Payakumbuh, 2020. Data Penerima PKH Kota Payakumbuh. Dinas Sosisal Kota Payakumbuh.

[3] Irwan, S.N.R., R. Rogomulyo, dan S. Trisnowati. 2018. Pemanfaatan pekarangan melalui pengembangan lanskap produktif di Desa Mangunan, Kabupaten Bantul Yogyakarta (Utilization of "pekarangan" throungh productive landscape development in Mangunan Village, Bantul District Yogyakarta). Jurnal Ilmu Pertanian Indonesia. 23 (2): 148-157.

[4] Badrie, N. dan A. G. Schauss. 2010. Sour sop (Annona muricata L.): Composition, Nutritional Value, Medicinal Uses, and Toxicology. Bioactive Foods in Promoting Health: Fruits and Vegetables. Elsevier, Washington.

[5] Setiavani, G., Sugiyono, A. B. Ahza, dan N. E. Suyatma. 2018. Teknologi pengolahan dan peningkatan nilai gizi dodol. Jurnal Pangan. 27 (3): 225-234.

[6] Chuah, T.G., H.H. Nisah, S.Y.T Choong, N.L. Chin, dan A. H. N. Sheikh. 2007. Effects of temperature on viscosity of dodol (concoction). Journal of Food Engineering. 80 (2): 423-430.

[7] Metropadang. 2020. PKH Payobasung Dilatih Politani Payakumbuh, Camat: Dua Tahun lagi Ibu-Ibu harus Keluar dari PKH. https://posmetropadang.co.id/. Diakses tanggal 20 November 2020. 